\section{NON-GOVERNMENTAL ORGANIZATIONS}

ICEL

The IUCN environmental law information system (ELIS)

Conservation of the environment and the international law association (Prof. Helmut R. Külz)

Earth care

Elizabeth Haub Prize

NGO's at Nairobi

NGO's form Canada-U.S. environmental council

The wheel of law

Conseil Européen du droit de l'environnement

Presentation of Elisabeth Haub prize

Creation of the Institute for European Environmental Policy

IUCN governing assembly -

I. Open democracy

II. Welcoming address by Mobutu Sese Seko

International Congress in Kyoto (Eckard Rehbinder)

\title{
SELECTED DOCUMENTS
}

OECD principles concerning transfrontier pollution

Scandinavian convention on transfrontier pollution

A new United Nations structure for global economic co-operation

UN General Assembly resolution no. 3129 (XXVIII)

UNEP Governing Council decision no. 18 (II)

UNEP Governing Council decision no. 44 (III)

Charter of economic rights and duties of states

Report of the executive director of UNEP on cooperation concerning shared natural resources

International assembly of NGO's concerned with the environment

Final Act of the Conference on Security and Cooperation in Europe

Agreement between U.S. and Canada on weather modification

Third UN conference on the law of the sea - informal single negotiating text

\section{BOOK NOTES}

The titanic effect - Planning for the unthinkable

United States experience with the preparation and analysis of environmental impact statements The National Environmental Policy Act

A scientific and policy review of the final environmental statement for the initial stage. Garrison Diversion Unit

Legal protection of natural environment in Poland

The management of urban change in Britain and Germany

Environmental laws and regulations in Japan

The control of the sea-bed - A new international issue

Environmental impact assessment: Principles and procedures

Shoreline for the public

International Environment Programmes

A summary of town and country planning law and the law of compulsory purchase and compensation

Streets for people

Ecotopia

Yerba Buena: Land grab and community resistance in San Francisco

Weather modification in the public interest

Environmental impact statement

102 Private remedies for transfrontier environmental disturbances

The international law of pollution

Control of pollution act 1974

A clear view - Guide to ind ustrial pollution control

Environmental policy and administration

Special depreciation allowances or subsidies?

International environmental law - Multilateral treaties Environmental law handbook

The polluter pays principle

Man and his environment - Policy and administration

Consumer health and product hazards

Law of the sea - Caracas and beyond

\section{Author Index of Volume 1}

Ahmed, Hassan, 50

Anderson, D. H., 71

Ashford, Nicholas A., 172

Biswas, Asit K., 160

Biswas, Margaret R., 160

Boisserée, Klaus, 22, 183

Bothe, Michael, 136

Burhenne, W. E., 101

Callary, Stephen, 71, 75

Cano, Guillermo J., 177

de Klemm, Cyrille, 10

Fleischer, Carl August, 120

Foriers, Paul, 99

Forster, Malcolm J., 185
Grossmann, Richard L., 141

Hartkopf, Günther, 166

Heaton, George R., 172

Isaacs, Allen, 145

Kimminich, O., 28

Külz, Helmut R., 42

Lamarque, Jean, 24

Lutz, Robert E., 132, 162

McCaffrey, Stephen C., 2

Mattes, Martin A., 53, 86, 136

Miki, Robert T., 169

Mobuto Sese Seko, 197
Nomura, Yoshihiro, 179

Orleans, Leo A., 189

Rehbinder, Eckard, 198

Rest, Alfred, 127

Roberts, E. F., 185

Robinson, Nicholas A., 93

Sand, Peter H., 154

Streibl, Max, 138

Strong, Ann L., 82

Stutzin, Godofredo, 38, 139

Train, Russell, 78

van Hoogstraten, Steven, 73

Winder, Jr., John S., 93 